\title{
The role of nitrogen in promoting the toxic cyanophyte Cylindrospermopsis raciborskii in a subtropical water reservoir
}

\author{
Michele A. Burford ${ }^{1}$, Karen L. McNeale ${ }^{1}$, Fiona J. McKenzie-Smith ${ }^{2}$ \\ ${ }^{1}$ Centre for Riverine Landscapes, Faculty of Environmental Science, \\ Griffith University, Nathan 4111, Australia \\ ${ }^{2}$ SEQWater, PO Box 15236, Brisbane City East, 4002, Australia
}

Running head: C. raciborskii and nitrogen

Corresponding author:

Michele Burford

Centre for Riverine Landscapes, Faculty of Environmental Science,

Griffith University, Nathan 4111, Australia

Email: $\underline{\text { m.burford@griffith.edu.au }}$

Phone: +61 73735 6723, Fax: +61 737357615

Keywords: algae, water storages, toxic algae, ammonium, nitrogen fixation 


\section{Summary}

1. The relative contribution of dissolved and atmospheric nitrogen to promoting dominance of the toxic nitrogen-fixing cyanobacterium, Cylindrospermopsis raciborskii was examined in a subtropical water reservoir, North Pine Reservoir.

2. A combination of process studies in situ and analysis of historical water quality data suggests that nitrogen fixation was not the principal mechanism for acquiring nitrogen and unlikely to be the mechanism whereby C. raciborskii gains a competitive advantage. Ammonium was the preferred nitrogen source, followed by nitrate then nitrogen fixation.

3. Ammonium uptake rates in the euphotic zone were higher in the summer and autumn months compared with winter and spring coinciding with lower ammonium concentrations. Nitrate uptake rates did not appear to vary seasonally and were lower than those for ammonium in the summer, but similar in winter. Nitrate concentrations were higher in winter than summer and generally higher than ammonium concentrations.

4. Ammonium and nitrate uptake rates were similar at light intensities between 10 and $100 \%$ of surface light, contrasting with primary productivity which peaked between about 10 to $20 \%$ of surface light. Thus the phytoplankton population was adapted to low light conditions but remained able to utilise dissolved inorganic nitrogen over a wide range of light conditions.

5. The ammonium pool in the surface waters was relatively small compared with the phytoplankton uptake rates, and ammonium must therefore be rapidly recycled through the food web over periods of less than one hour. Short term 
depletion may result, during which time the higher concentrations of nitrate are likely to provide a supplementary supply of nitrogen.

6. The dominance of C. raciborskii in this reservoir is more likely to be due to a superior ability to scavenge and store the low concentrations of phosphate, and a superior adaptation to the low light conditions exacerbated by artificial mixing. 


\section{Introduction}

The cyanobacterium, Cylindrospermopsis raciborskii (Wołoszyńska) Seenayya and Subba Raju is a subtropical/tropical species that dominates lakes and water reservoirs in many countries, including Brazil, Australia, USA and Hungary (Padisák, 1997). It is a solitary, filamentous diazotroph that appears to be invading more freshwaters across a diversity of habitats, with predictions that it will increasingly inhabit European lakes within the next 10 to 20 years. There are recent accounts of the appearance of this species in Portugal and France (Briand et al., 2002; Saker et al., 2003). The Australian strain of C. raciborskii produces an alkaloid cytotoxin, cylindrospermopsin, and the Brazilian strain produces paralytic shellfish poisoning (PSP) toxins (Neilan et al., 2003). It has been linked with a major poisoning incident on Palm Island, Queensland, Australia in 1979 when 149 people became ill, many requiring hospitalisation (Hawkins et al., 1985; Falconer, 1996).

Analysis of water quality data from water reservoirs in Australia, Brazil and Europe has revealed a correlation between C. raciborskii blooms and many factors: high temperatures, vertical water stratification, resistance to grazing, long water residence times, and high concentrations of phosphate, ammonium, nitrate and iron (Dokulil \& Mayer, 1996; de Souza et al., 1998; McGregor \& Fabbro, 2000; Bouvy et al., 1999, 2000, 2001). A review of C. raciborskii ecology suggests that high ammonium and phosphate affinity, and the ability to fix nitrogen, have been key factors in the success of C. raciborskii throughout the world (Padisák, 1997). 
North Pine Reservoir, a drinking water reservoir in southeast Queensland has had severe summer blooms of C. raciborskii since the 1980s with resultant concentrations of the toxin, cylindrospermopsin, being detected. An analysis of this data in the mid 1990s suggested that C. raciborskii blooms dominated during drier years, and when the water column was more stable (Harris \& Baxter, 1996). It was concluded that vertical stratification and low nitrogen inputs were likely to provide the competitive advantage for C. raciborskii over other algal species. The installation of a destratification unit in North Pine Reservoir in the mid 1990s designed to reduce stratification and sediment remineralisation of nutrients, and hence reduce C. raciborskii dominance, had the opposite effect. Blooms now commence earlier and are more sustained (Antenucci et al., 2005; Burford \& O’Donohue, 2006).

In contrast to Harris \& Baxter (1996), Antenucci et al. (2005) have suggested that the dominance of C. raciborskii in North Pine Reservoir prior to installation of the destratification unit was due to it's ability to compete for phosphate, and increased dominance post-destratification due to the ability to compete for light. Another study which compared North Pine Reservoir with two adjacent naturally mixed reservoirs suggested that the dominance of C. raciborskii post-destratification was also linked to a superior phosphate scavenging ability (Burford \& O’Donohue, 2006). However, the role of nitrogen sources in promoting $C$. raciborskii has received less attention. This study attempted to resolve the question of whether nitrogen fixation also plays an important role in promoting C. raciborskii in North Pine Reservoir by using a combination of in situ process studies and analysis of long-term water quality data. 


\section{Methods}

Study area

The study was conducted at North Pine Reservoir which is located in subtropical, southeast Queensland, Australia, and provides a source of drinking water to the city of Brisbane and a number of regional towns and cities. The catchment for this reservoir is typically rural, and is dominated by cattle grazing pasture $(>50 \%)$, with approximately $20 \%$ natural vegetation.

North Pine Reservoir (Lake Samsonvale, $27^{\circ} 15^{\prime} \mathrm{S}, 152^{\circ} 55^{\prime} \mathrm{E}$ ) has an area of $21.8 \mathrm{~km}^{2}$ and 215,000 ML full reservoir volume (Table 1). An artificial destratification system was installed in the lower reaches of the reservoir and began operating in 1995. The system is typically switched on in mid-September and runs over the summer each year. It consists of two diffusers, made of polyethylene pipe, each being approximately $550 \mathrm{~m}$ long. Each diffuser discharges at least $200 \mathrm{~L} \mathrm{~s}^{-1}$ air at the depth of the diffuser and was installed $1 \mathrm{~m}$ above the sediment surface.

Rainfall data were collected by the Australian Bureau of Meteorology (BOM, www.bom.gov.au) from 1997 to 2005 using rain gauges located at the reservoir (Table 1). Maximum and minimum ambient temperatures were also measured by $\mathrm{BOM}$ at the nearest temperature recording site, Brisbane Airport.

\section{Historical water quality sampling}

Water samples were collected $100 \mathrm{~m}$ west of the reservoir wall, biweekly for phytoplankton counts and monthly for nutrients from July 1997 until June 2005 
(excluding July 2002 to June 2003), as part of SEQWater's water quality monitoring program. A $3 \mathrm{~m}$ long hosepipe sampler ( $5 \mathrm{~cm}$ dia.) was used to collect a depthintegrated sample. After mixing in a bucket, a subsample of $250 \mathrm{~mL}$ was collected in a polyethylene bottle for phytoplankton counts. $1 \mathrm{~mL}$ of $100 \%$ Lugols solution was added and samples were stored in the dark until counted. A subsample of water was filtered through a $0.45 \mu \mathrm{m}$ membrane filter and frozen for subsequent analysis of soluble nutrients. A water sample was also taken $1 \mathrm{~m}$ from the bottom of the water column, using a van Dorn sampler, for nutrient analyses. Profiles of temperature, conductivity, $\mathrm{pH}$, oxygen and turbidity were also determined through the water column with an automated logger (Sonde YSI 6600 multiparameter and YSI650 handheld).

In the laboratory, samples were counted under phase-contrast microscopy using a Sedgewick Rafter counting chamber. A minimum of 30 fields and 100 algal units were counted to yield a final result of $\pm 20 \%$ of the true cell concentration (Lund et al., 1958). Ammonium, nitrate, phosphate and silicate were analysed using standard colorimetric methods from the American Public Health Association, 1995 (QHSS).

\section{Process studies}

\section{$\underline{\text { Phytoplankton nitrogen uptake and fixation }}$}

Nitrogen uptake and nitrogen fixation rates by phytoplankton in North Pine Reservoir were determined using ${ }^{15} \mathrm{~N}$-nitrogen uptake and acetylene reduction methods (Knowles, 1990; Glibert et al., 1991). Sampling for ${ }^{15} \mathrm{~N}$-nitrogen uptake and nitrogen fixation experiments was conducted six times over a one year period (3 February, 7 April, 9 June, 28 August, 10 November 2004, 13 January 2005). Water samples were 
collected using a $3 \mathrm{~m}$ depth-integrated sampler $100 \mathrm{~m}$ from the reservoir wall (same site as historical water quality samples). Water was transported to a laboratory at the shore and used to fill acid-washed $500 \mathrm{~mL}$ polycarbonate bottles. Two concentrations each of ${ }^{15} \mathrm{~N}$-ammonium chloride or potassium nitrate $(0.07$ and $0.71 \mu \mathrm{M} \mathrm{N}$, respectively) were added to duplicate bottles incubated at 0 and $100 \%$ light. One of the two concentrations was used in the analysis to ensure that addition rates were in the range of $10 \%$ of background nitrate and ammonium concentrations. Bottles were incubated by attaching them to a mesh rack floating in the reservoir for $1 \mathrm{~h}$. To detect the effect of irradiance on uptake rates, two replicates at five light levels (100\%, $50 \%, 30 \%, 10 \%$ and $0 \%$ ) were incubated using the same protocol as above on four occasions (February, August, November 2004, January 2005). On one occasion, the ammonium uptake rate was determined for duplicate bottles in $30 \%$ light over a range of incubation times $(3,30,45,90,140 \mathrm{~min})$ to ensure linearity of uptake over the incubation time $(1 \mathrm{~h})$ chosen for the incubations. Linearity of uptake was achieved up to $140 \min \left(\mathrm{r}^{2}=0.98\right)$.

Following incubation, known volumes from each bottle were filtered using $25 \mathrm{~mm}$ pre-combusted GF/F filters, and filters were frozen. In the laboratory, filters were dried and the ${ }^{15} \mathrm{~N} /{ }^{14} \mathrm{~N}$ isotopic ratio, \% nitrogen and \% carbon was determined using a mass spectrometer (GV Isoprime, Manchester UK). Uptake rates were calculated using the equations of Glibert et al. (1991). Relative preference indices (RPI) were calculated using the equations of McCarthy, Taylor \& Taft (1977) to determine whether the phytoplankton community preferred ammonium or nitrate. The equation for ammonium preference is shown below: 


$$
\operatorname{RPI}\left(\mathrm{NH}_{4}\right)=\frac{\left(\mathrm{NH}_{4} \text { uptake }\right) /\left(\mathrm{NH}_{4} \text { uptake }+\mathrm{NO}_{3} \text { uptake }\right)}{\left[\mathrm{NH}_{4}\right] /\left(\left[\mathrm{NH}_{4}+\mathrm{NO}_{3}\right]\right)}
$$

In the case of nitrate preference, nitrate values were substituted for ammonium values.

A subsample of water collected for the ${ }^{15} \mathrm{~N}$-uptake experiments was also used to fill $500 \mathrm{~mL}$ glass bottles for nitrogen fixation measurements. Acetylene gas, prebubbled through water to remove contaminants, was bubbled into the sample in the sealed bottles for $5 \mathrm{~min}$ to ensure saturation of the water with acetylene. Triplicate bottles were incubated at five light levels $(100,50,30,10$ and $0 \%)$ for $24 \mathrm{~h}$. Temperature was logged throughout the incubations in an additional bottle using a sensor (ETemperature, On Solutions). $5 \mathrm{~mL}$ subsamples were withdrawn from the bottles into venoject vials containing $0.2 \mathrm{~mL} 20 \%$ trichloroacetic acid to halt nitrogen fixation at 0,4 and $24 \mathrm{~h}$. Samples were stored at $4{ }^{\circ} \mathrm{C}$ until analysed. A gas chromatograph with a flame ionization detector was used to determine the ethylene content of the samples. Nitrogen fixation rates were calculated from the conversion of acetylene to ethylene (Knowles, 1990).

Subsamples were also taken for determination of ammonium, nitrate/nitrite and phosphate concentrations. Water was filtered through $0.45 \mu \mathrm{m}$ cellulose filters and stored on ice until returned to the laboratory. Nutrients were analysed using standard colorimetric methods (American Public Health Association, 1995).

Subsamples were also taken for algal counts and fixed in 100\% Lugol's solution. Samples were counted as described previously. Heterocyst numbers and frequency were recorded for C. raciborskii by counting 100 fields or 100 trichomes. 


\section{Primary productivity experiments}

Measurements of primary productivity were done four times over a one year period ( 5 February, 9 June 2004, 12 January, 13 January 2005) in North Pine Reservoir. Water samples were collected using the same technique and at the same site and time as for the nitrogen fixation and uptake experiments. Coincident light profiles through the water column were measured using a 4 pi sensor (Licor). Water was placed in acidwashed plastic bottles and subjected to a range of light levels. For the first two sampling occasions, $500 \mathrm{~mL}$ polycarbonate bottles were used, thereafter $350 \mathrm{~mL}$ PET drink bottles were used. There were five treatments for the first three sampling occasions $(100,50,14,5$ and $0 \%$ light $)$ increasing to 6 treatments $(100,50,25,14,5$ and $0 \%$ light) for the last two sampling occasions in order to more fully characterise the photosynthesis-irradiance curve. All bottles for treatments less than $100 \%$ light were placed in bags made of shade cloth to screen light to the required intensity. There were three replicates for each treatment. $20 \mu \mathrm{Ci}{ }^{14} \mathrm{C}$-bicarbonate (specific activity of 1.11 to $2.22 \mathrm{GBq} \mathrm{mmol}^{-1}\left(30\right.$ to $\left.60 \mathrm{mCi} \mathrm{mmol}^{-1}\right)$ ) was added to the bottles.

Samples were incubated by securing them on a mesh rack floating in the reservoir for $4 \mathrm{~h}$. The ambient light intensity was logged every $10 \mathrm{~min}$ during the incubation. The water temperature near the bottles was also monitored using a temperature logger (Etemperature, OnSolutions). After $4 \mathrm{~h}$, incubations were stopped by placing bottles in black bags. Known volumes of water were filtered onto $0.2 \mu \mathrm{m}$ polycarbonate filters. $0.2 \mathrm{~mL} 6 \mathrm{~N}$ hydrochloric acid was added to each filter in scintillation vials to halt uptake. After allowing samples to vent, water and scintillation fluid were added 
and samples were counted in a scintillation counter (Packard). Uptake rates were calculated as per Parsons et al. (1984).

Subsamples of the water collected near the dam wall were taken for chlorophyll $a$ analysis and alkalinity. For chlorophyll analysis, known volumes of water were filtered through glass fibre filters. The filters were then frozen until returned to the laboratory. Filters were extracted by sonicating for $1 \mathrm{~min}$ in cold $100 \%$ acetone, and extracts were measured spectrophotometrically after adjusting the acetone concentration to $90 \%$, when there was sufficient chlorophyll, and with a spectrofluorometer when chlorophyll values were low (Jeffrey \& Welshmeyer, 1997). The spectrophotometric values were then used to calibrate the fluorescence readings. Water for alkalinity analysis was stored in plastic vials on ice until analysed in the laboratory using the method of the American Public Health Association (1995).

\section{Results}

\section{Historical water quality}

The climate of southeast Queensland, where the reservoir is situated, is warm and wet in the summer (December-February, monthly mean max. temperature $28.4-31.4^{\circ} \mathrm{C}$ ), and mild and dry in the winter (May-July, monthly mean max. temperature 20.8$\left.23.3^{\circ} \mathrm{C}\right)$.

Mean monthly nitrate concentrations at the dam wall site in the reservoir were highly variable but generally higher at the bottom than surface in spring (August - October) (Fig. 1). Concentrations were typically highest in late summer through winter months, particularly in surface waters, with concentrations up to $10.7 \mu \mathrm{M}$ N. In 
contrast, ammonium concentrations were generally below $3.6 \mu \mathrm{M} \mathrm{N}$ with the exception of summer peaks (November - March) in bottom waters (Fig. 1). Phosphate concentrations were typically near the minimal detection limits $(0.06 \mu \mathrm{M})$ with no obvious differences seasonally or between surface and bottom (Fig. 1).

Total phytoplankton densities peaked in the summer (December -February) each year

(Fig. 2). C. raciborskii densities also peaked each summer and in some summers, C. raciborskii dominated the algal community.

\section{Process studies}

Process studies were conducted from February 2004 to January 2005. Water temperatures during the incubations ranged from 17.4 to $27.2^{\circ} \mathrm{C}$ (Table 2). Ammonium and nitrate concentrations were highly variable, i.e. 0.12 to 6.71 , and 0.64 to $8.57 \mu \mathrm{M}$, respectively. Phosphate concentrations were generally near the detection limit $(0.06 \mu \mathrm{M})$. Dissolved inorganic nitrogen:phosphate ratios were always substantially higher than the Redfield (1985) molar ratio of 16:1 with the exception of November 2004 when the ratio was lower than 16:1.

Cyanobacteria were the dominant phytoplankton group in the surface $3 \mathrm{~m}$ at the reservoir wall site in North Pine Reservoir at each of the sampling occasions (Fig. 3). The most numerically dominant genus during the winter months was the colonial species, Aphanocapsa, while in summer there was a mix of colonial cyanobacteria (Aphanocapsa, Aphanothece and on one occasion, Cyanodictyon) and filamentous species (C. raciborskii and Planktolyngbya). However, of the four most dominant genera, C. raciborskii, Aphanocapsa, Planktolyngbya and Aphanothece, the 
biovolume of C. raciborskii was highest in the summer, while Aphanocapsa was highest in the winter (Fig. 4).

Maximum ammonium uptake rates ranged from 0.19 to $3.70 \mu \mathrm{M} \mathrm{h}^{-1}$ over the year of the study with February and April 2004 and January 2005 having the highest rates (Fig. 5). Nitrate uptake rates were lower $\left(0.04\right.$ to $\left.0.39 \mu \mathrm{M} \mathrm{h}^{-1}\right)$ than those for ammonium in summer but similar in winter and spring. Both ammonium and nitrate uptake rates were lower in the dark than the light (64 and 85\%, respectively, of uptake rates in the light). Non biomass-specific uptake (v) varied considerably between sampling occasions but in the case of ammonium the highest rates were noted in the warmest water temperatures $\left(\mathrm{R}^{2}=0.42\right)$. Highest rates of non biomass-specific uptake coincided with the highest rates of biomass-specific uptake, i.e. uptake multiplied by particulate nitrogen concentrations (Table 3, Fig. 5).

Based on maximum uptake rates and background ammonium concentrations, the turnover time for ammonium in the water column ranged from 0.3 to $5.8 \mathrm{~h}$ (Table 3). In contrast, the nitrate turnover time was much higher ranging from 3.5 to $218 \mathrm{~h}$. Ammonium was the preferred source, as determined by the relative preference indices for ammonium and nitrate (a higher value denotes a higher level of preference). Turnover times for particulate nitrogen were faster in summer (1.9 to $7.2 \mathrm{~h}$ ) than winter (24.3 to $25.5 \mathrm{~h})$.

Nitrogen fixation rates were also measured five times over the year. Values were below the detection limit of the method $\left(<0.005 \mu \mathrm{M} \mathrm{h}^{-1}\right)$ except in August and November 2004 when low rates $\left(0.03\right.$ and $0.02 \mu \mathrm{M} \mathrm{h}^{-1}$, respectively) were measured 
(Table 3). Heterocysts were only observed on C. raciborskii trichomes (30\% of trichomes) in November 2004.

There was generally little change in nitrate and ammonium uptake rates over light levels ranging from 10 to $100 \%$ when measured in February, August, November 2004, and January 2005 (Fig. 6). This contrasted with primary productivity rates (measured in February, June 2004 and January 2005) which peaked between 115 to $300 \mu \mathrm{mol} \mathrm{m} \mathrm{s}^{-1}$ PAR $\left(\mathrm{I}_{\mathrm{K}}, 10-20 \%\right.$ of surface light), with lower rates at both higher and lower light intensities (Table 4).

\section{Discussion}

This study showed that in North Pine reservoir, ammonium and nitrate uptake occurred at a faster rate than nitrogen fixation. Additionally, both these nutrients were present in detectable, and at times, high concentrations since 1997. This, coupled with high dissolved inorganic nitrogen:phosphorus ratios suggests that nitrogen is unlikely to be limiting phytoplankton growth. C. raciborskii was the algal species with the highest biovolume, particularly in the summer months, over the course of the study. Therefore the nitrogen-fixing capacity that has often been suggested as one of the reasons why C. raciborskii dominates in lakes and reservoirs is unlikely to be an explanation in North Pine reservoir (Harris \& Baxter, 1996; Padisák, 1997; Dokulil \& Teubner, 2000; McGregor \& Fabbro, 2000). The summer dominance of

C. raciborskii matches findings in many other water reservoirs in tropical and subtropical Australia, Brazil, and increasingly in temperate lakes and reservoirs (Bouvy et al., 2000; McGregor \& Fabbro, 2000; Padisák, 1997; Burford \& O’Donohue, 2006). The colonial cyanobacteria, Aphanocapsa, and Aphanothece, and 
the solitary filamentous genus Planktolyngbya were also numerically dominant in North Pine reservoir. This is consistent with a previous study in this reservoir that found a dominance of these species over five years (Burford \& O'Donohue, 2006).

Ammonium was the preferred source during the process studies but given the rapid turnover times for this pool, it is likely that ammonium limitation occurred periodically. Since nitrate availability was higher, it is therefore likely to satisfy the nitrogen demands of the phytoplankton when ammonium was limiting. Uptake rates of ammonium and nitrate were comparable with those in Lake Balaton, a temperate lake in Hungary, which has summer blooms of C. raciborskii, and slightly lower than a temperate eutrophic lake in the USA (Présing et al., 2001; Ferber et al., 2004). Laboratory studies show that $C$. raciborskii preferentially uses ammonium and nitrate over atmospheric nitrogen (Spröber et al., 2003). In addition, faster growth rates were achieved when ammonium was used as the source, followed by nitrate then nitrogen fixation (Shafik et al., 2001). It is more energetically advantageous for phytoplankton to utilise ammonium, making it the preferred source (Raven, 1984; Dortch, 1990).

Ammonium and nitrate uptake rates were similar at light intensities between 10 and $100 \%$ of surface light. Uptake also occurred in the dark, over $1 \mathrm{~h}$ incubations, but at a lower rate. This implies, at least in the short term, that nitrogen uptake can occur below the euphotic zone, as has been observed elsewhere (Ferber et al., 2004). As such, the phytoplankton community in North Pine Reservoir was likely adapted to scavenging dissolved nitrogen throughout the euphotic zone and below. In such cases, the operation of the destratification unit to increase mixing below the euphotic zone is unlikely to have significantly affected dissolved nitrogen uptake. In contrast 
to the wide light range for nitrogen uptake, primary productivity rates in the reservoir were highest at low light levels, i.e. 10 to $20 \%$ of surface light, although depthintegrated areal primary productivity rates and chlorophyll $a$ concentrations were comparable with a number of temperate reservoirs (Knoll et al., 2003; Présing et al., 2001). Shafik et al. (2001), in culture experiments, also found optimal growth of C. raciborskii at relatively low light levels. As this species is capable of buoyancy regulation, it may be that it is able to optimise both light and nutrient uptake to outcompete other species (Padisák, 1997). The role of buoyancy in optimising growth warrants further attention.

A nitrogen budget was constructed for North Pine Reservoir based on measured nitrogen concentrations and nitrogen uptake rates at the reservoir wall site (Fig. 7). Phosphorus demand were inferred based on Redfield (1958) molar ratios for nitrogen:phosphorus of 16:1. The budget highlights the importance of ammonium cycling in supplying the ammonium requirements of the phytoplankton. Ammonium could be supplied from a range of sources: input water, regeneration by bacteria, zooplankton and other animal species in the water column, and sediment remineralisation processes. Sediment remineralisation may be a significant source since ammonium concentrations were higher in bottom waters compared with the surface waters, and the mechanism for mixing ammonium into surface waters may be the destratification unit. The rapid internal cycling of ammonium is consistent with findings in temperate lakes (Présing et al., 2000; Ferber et al., 2004).

The nitrate pool was larger and uptake was lower than for ammonium, while nitrogen fixation was a minor source of nitrogen for phytoplankton. Compounds such as urea 
and free amino acids in the dissolved organic nitrogen (DON) pool can also be utilised by a wide range of phytoplankton (Berman \& Bronk, 2003). Given the large pool of DON in North Pine Reservoir, it is possible that such compounds contribute to the nitrogen requirements of the phytoplankton community. Présing et al. (2001) found urea to be a significant nitrogen source in a lake with summer blooms of C. raciborskii.

Based on the Redfield (1958) ratios for nitrogen vs. phosphorus demands of phytoplankton, phosphate cycling would need to be very rapid $(\sim 5 \mathrm{~h})$ to satisfy the phosphate requirements of the phytoplankton (Fig. 7). The high ratio of molar total nitrogen:total phosphours in this reservoir of 65:1 combined with rapid cycling times suggests phosphorus limitation, therefore phosphate may not be cycled sufficiently rapidly to ensure optimal phytoplankton growth. However, the low concentrations may be providing the competitive advantage for phosphorus scavenging species such as C. raciborskii (Istvànovics et al., 2000). Further work on phosphate uptake rates and particulate carbon:phosphorus ratios is needed to substantiate the hypothesis of phosphate limitation and species selection.

In conclusion, this study suggests that nitrogen fixation was not the mechanism promoting C. raciborskii dominance in North Pine Reservoir. Other likely explanations are the ability to scavenge and store phosphorus (Burford \& O'Donohue, 2006) and the ability to utilise low light conditions promoted by use of the destratification unit (Antenucci et al., 2005). Other possible reasons such as allelopathic effects on other phytoplankton and toxic effects on grazers are also less well understood, but warrant further study. 


\section{Acknowledgments}

We wish to thank the staff at SEQWater for undertaking sampling, Rene Diocares for providing advice on gas chromatography and undertook the mass spectrometry, Mick Sievers and Ben Reynolds for retrieving historical data, Dan Wruck and his team at Queensland Health for undertaking nutrient analyses and algal counts, Tony Weber for providing the modelled nutrient input load data; Justin Brookes and Cathy Leigh for critically reviewing the manuscript. This study was funded by the Awwa Research Foundation, SEQWater and the Brisbane City Council. 


\section{References}

Antenucci J., Ghanouani A., Burford M. \& Romero J. (2005) The impact of artificial destratification on phytoplankton species composition in a sub-tropical reservoir. Freshwater Biology, 50, 1081-1093.

American Public Health Association (APHA) (1995) Standard Methods for the Examination of Water and Wastewater. 20th Edition, Eds. Greenburg, A.E., Clesceri, L.S., Eaton, A.D. American Public Health Association, Washington, D.C.

Berman T. \& Bronk D.A. (2003) Dissolved organic nitrogen: a dynamic participant in aquatic ecosystems. Aquatic Microbial Ecology, 31, 279-305.

Bouvy M., Molica R., de Oliveria S., Marinho M. \& Beker B. (1999) Dynamics of a toxic cyanobacterial bloom (Cylindrospermopsis raciborskii) in a shallow reservoir in the semi-arid region of northeast Brazil. Aquatic Microbial Ecology, 20, 285-297.

Bouvy M., Dalcão D., Marinho M., Pagano M. \& Moura A. (2000) Occurrence of Cylindrospermopsis raciborskii (Cyanobacteria) in 39 tropical reservoirs during the 1998 drought. Aquatic Microbial Ecology, 23, 13-27.

Bouvy M., Pagano M. \& Troussellier M. (2001) Effects of a cyanobacterial bloom (Cylindrospermopsis raciborskii) on bacteria and zooplankton communities in Ingazeira reservoir (northeast Brazil). Aquatic Microbial Ecology, 25, 215-227. Briand J.F., Robillot C., Quibler-Llobéras C., Humbert J.F., Couté A. \& Bernard C. (2002) Environmental context of Cylindrospermopsis raciborskii (Cyanobacteria) blooms in a shallow pond in France. Water Research, 36, 3183-3192. 
Burford M.A. \& O’Donohue M.J. (2006) A comparison of phytoplankton community assemblages in artificially and naturally mixed subtropical water reservoirs. Freshwater Biology, 51, 973-982.

de Souza R.C.R., Carvalho M.C. \& Truzzi A.C. (1998) Cylindrospermopsis raciborskii (Wolosz.) Seenaya and Subba Raju (Cyanophyceae) dominance and a contribution to the knowledge of Rio Pequeno Arm, Billings Reservoir, Brazil. Environmental Toxicology and Water Quality, 13, 73-81.

Dokulil M.T. \& Mayer J. (1996) Population dynamics and photosynthetic rates of a Cylindrospermopsis - Limnothrix association in a highly eutrophic urban lake, Alte Donau, Vienna, Austria. Algological Studies, 83, 179-195.

Dokulil M.T. \& Teubner K. (2000) Cyanobacterial dominance in lakes. Hydrobiologia, 438, 1-12.

Dortch Q. (1990) The interaction between ammonium and nitrate uptake in phytoplankton. Marine Ecology Progress Series, 61, 183-201.

Falconer I.R. (1996) Cylindrospermopsis - A health risk or just a nuisance? Cylindrospermopsis - A New Toxic Algal Bloom Challenge for Australia. Agricultural and Resource Management Council of Australia and New Zealand, Brisbane, Australia.

Ferber L.R., Levine S.N., Lini A. \& Livingston G.P. (2004) Do cyanobacteria dominate in eutrophic lakes because they fix atmospheric nitrogen? Freshwater Biology, 49, 690-708.

Glibert P.M., Garside C., Fuhrman J.A. \& Roman M.R. (1991) Time-dependent coupling of inorganic and organic nitrogen uptake and regeneration in the plume of the Chesapeake Bay estuary and its regulation by large heterotrophs. Limnology and Oceanography, 36, 895-909. 
Harris G.P. \& Baxter G. (1996) Interannual variability in phytoplankton biomass and species composition in a subtropical reservoir. Freshwater Biology, 35, 545-560

Hawkins P.R., Runnegar M.T.C., Jackson A.R.B. \& Falconer I.R. (1985) Severe hepatotoxicity caused by the tropical cyanobacterium Cylindrospermopsis raciborskii (Woloszyńska) Seenya and Subba Raju isolated from a domestic water supply reservoir. Applied and Environmental Microbiology, 50, 1292-1295.

Istvànovics V., Shafik H.M., Présing M. \& Juhos S. (2000) Growth and phosphate uptake kinetics of the cyanobacterium, Cylindrospermopsis raciborskii (Cyanophyceae) in throughflow cultures. Freshwater Biology, 43, 257-275.

Jeffrey S.W. \& Welshmeyer N.A. (1997) Spectrophotometric and fluorometric equations in common use in oceanography. In: Phytoplankton Pigments in Oceanography. Monographs on Oceanographic Methodology No.10. (eds. S.W. Jeffrey, R.F.C. Mantoura \& S.W. Wright), pp. 597-615. UNESCO Publishing, Paris.

Knoll L.B., Vanni M.J. \& Renwick W.H. (2003) Phytoplankton primary production and photosynthetic parameters in reservoirs along a gradient of watershed land use. Limnology and Oceanography, 48, 608-617

Knowles R. (1990) Acetylene inhibition techniques: Development, advantages, and potential problems. In: Denitrification in Soil and Sediment. (eds. N.P. Revsbech, \& J. Sørensen) pp. 151-166, Plenum Press, New York.

Lund J.W.G., Kipling C. \& Le Cren E.D. (1958) The inverted microscope method of estimating algal numbers and the statistical basis for counting. Hydrobiologia, 11, 143-170. 
McCarthy J.J., Taylor W.R. \& Taft, J.L. (1977) Nitrogenous nutrition of the plankton in the Chesapeake Bay. I. Nutrient availability and phytoplankton preferences. Limnology and Oceanography, 22, 996-1011.

McGregor G.B. \& Fabbro L.D. (2000) Dominance of Cylindrospermopsis raciborskii (Nostocales, Cyanoprokaryota) in Queensland tropical and subtropical reservoirs: Implications for monitoring and management. Lakes and Reservoirs: Research and Management, 5, 195-205.

Neilan B.A., Saker M.L., Fastner J., Törökné A. \& Burns B.P. (2003) Phylogeography of the invasive cyanobacterium Cylindrospermopsis raciborskii. Molecular Ecology, 23, 133-140.

Padisák J. (1997) Cylindrospermopsis raciborskii (Wołoszyńska) Seenayya and Subba Raju, an expanding highly adaptive cyanobacterium: Worldwide distribution and review of its ecology. Archiv fur Hydrobiologie. Supplementbund. Monographic Studies, 107, 563-593.

Parsons T.R., Maita Y. \& Lalli C.M. (1984) A Manual of Chemical and Biological Methods for Seawater Analysis. Pergamon Press, Oxford. 173 pp.

Présing M., Herodek S., Preston T. \& Vörös L. (2001) Nitrogen uptake and the importance of internal nitrogen loading in Lake Balaton. Freshwater Biology, 46, 125-129.

Raven J.A. (1984) A cost-benefit analysis of photon absorption by photosynthetic unicells. New Phycologist, 98, 593-625.

Redfield A.C. (1958) The biological control of chemical factors in the environment. American Science, 46: 205-222.

Saker M.L., Nogueira C.G., Vasconcelos V.M., Neilan B.A., Eaglesham G.K. \& Pereira P. (2003) First report and toxicological assessment of the cyanobacterium 
Cylindrospermopsis raciborskii from Portuguese freshwaters. Ecotoxicology and Environmental Safety, 55, 243-250.

Shafik H.M., Herodek S., Présing M. \& Vörös L. (2001) Factors affecting growth and cell composition of cyanoprokaryote Cylindrospermopsis raciborskii

(Woloszynska) Seenayya et Subba Raju. Archiv Hydrobiologie, Algological Studies, 103, 75-93.

Sprőber P., Shafik H.M., Présing M., Kovács A.W. \& Herodek S. (2003) Nitrogen uptake and fixation in the cyanobacterium Cylindrospermopsis raciborskii under different nitrogen conditions. Hydrobiologia, 506-509, 169-174. 


\section{Figure legend}

Figure 1: Mean $( \pm \mathrm{SD})$ monthly surface and bottom water ammonium, nitrate and phosphate concentrations $(\mu \mathrm{M})$ in $3 \mathrm{~m}$ depth-integrated surface waters in North Pine reservoir from July 1997 to June 2005.

Figure 2: Total algal and C. raciborskii cell densities in $3 \mathrm{~m}$ depth-integrated surface waters in North Pine reservoir from July 1997 to June 2005.

Figure 3: Percentage of algal densities attributable to dominant genera during process studies in North Pine Reservoir from February 2004 to January 2005. CYAN = cyanobacteria, $\mathrm{CHLOR}=$ chlorophyte

Figure 4: Cell biovolumes $\left(\mathrm{mm}^{3} \mathrm{~L}^{-1}\right)$ of the four most dominant algal genera during process studies in North Pine Reservoir from February 2004 to January 2005. CYAN $=$ cyanobacteria.

Figure 5: Biomass-specific ammonium and nitrate uptake $\left(\mu \mathrm{M} \mathrm{N} \mathrm{h}^{-1}\right)$ at $100 \%$ light and dark in North Pine Reservoir water from February 2004 to January 2005. nd = no data

Figure 6: Biomass-specific ammonium and nitrate uptake $\left(\mu \mathrm{M} \mathrm{N} \mathrm{h}^{-1}\right)$ and primary productivity $\left(\mu \mathrm{M} \mathrm{C} \mathrm{h}^{-1}\right.$ ) over a range of light levels (\% of surface light) in North Pine Reservoir water from February 2004 to January 2005. 
Figure 7: Nitrogen and phosphorus pools $(\mathrm{T})$ and phytoplankton demand $\left(\mathrm{T} \mathrm{yr}^{-1}\right)$ in the water column in North Pine reservoir, based on measurements at the reservoir wall site. Phosphate demand was calculated using Redfield (1958) ratios. $\mathrm{NH}_{4}=$ ammonium, $\mathrm{NO}_{3}=$ nitrate, $\mathrm{PN}=$ particulate nitrogen, $\mathrm{DON}=$ dissolved organic nitrogen, $\mathrm{TN}=$ total nitrogen, $\mathrm{TP}=$ total phosphorus, $\mathrm{PO}_{4}=$ phosphate. 
Table 1: Physical attributes of North Pine Reservoir. Annual rainfall is an average for the period 1997-2002.

Parameter

Reservoir area $\left(\mathrm{km}^{2}\right)$

Full reservoir volume (ML)

Maximum depth at wall (m)

Catchment area $\left(\mathrm{km}^{2}\right)$

Rainfall (mm yr $\left.{ }^{-1}\right)$

Evaporation $\left(\mathrm{mm} \mathrm{yr}^{-1}\right)$
North Pine

215,000

35

347

1060

1375 
Table 2: Temperature, euphotic depth, $\mathrm{pH}$, nutrient and particulate nitrogen concentrations $(\mu \mathrm{M})$, chlorophyll $a$ concentrations $\left(\mu \mathrm{g} \mathrm{L}^{-1}\right)$ and dissolved inorganic nitrogen:phosphate molar ratios during each ${ }^{15} \mathrm{~N}$-uptake incubation. ${ }^{*}$ Nitrate/nitrate concentrations for this month were inferred from mean April data for North Pine Reservoir for the last 5 years. $\mathrm{Z}_{\mathrm{eu}}=$ euphotic depth, $\mathrm{PO}_{4}=$ phosphate, $\mathrm{NH}_{4}=$ ammonium, $\mathrm{NO}_{3}=$ nitrate, $\mathrm{PN}=$ particulate nitrogen. $\mathrm{PO}_{4}=$ phosphate, $\mathrm{NH}_{4}=$ ammonium, $\mathrm{NOX}=$ oxides of nitrogen, $\mathrm{PN}=$ particulate nitrogen, chl $a=$ chlorophyll $a, \mathrm{DIN}=$ dissolved inorganic nitrogen.

\begin{tabular}{|c|c|c|c|c|c|c|c|c|c|}
\hline Month & $\begin{array}{c}\text { Temp } \\
{ }^{\circ} \mathrm{C}\end{array}$ & $\begin{array}{l}Z_{\text {eu }} \\
m\end{array}$ & $\mathrm{pH}$ & $\begin{array}{l}\mathrm{PO}_{4} \\
(\mu \mathrm{M})\end{array}$ & $\begin{array}{l}\mathrm{NH}_{4} \\
(\mu \mathrm{M})\end{array}$ & $\begin{array}{l}\text { NOX } \\
(\mu \mathrm{M})\end{array}$ & $\begin{array}{l}\mathrm{PN} \\
(\mu \mathrm{M})\end{array}$ & $\begin{array}{r}\text { Chl } a \\
\left(\mu \mathrm{g} \mathrm{L}^{-1}\right)\end{array}$ & $\begin{array}{c}\text { Molar } \\
\text { DIN: } \mathrm{PO}_{4} \text { ratio }\end{array}$ \\
\hline February 2004 & 27.2 & 5.0 & 7.8 & $<0.06$ & 6.71 & 3.71 & 8.42 & 10.56 & 173 \\
\hline April 2004 & 24.8 & 2.9 & 7.4 & 0.06 & 1.93 & $8.57 *$ & 6.74 & 6.77 & 175 \\
\hline June 2004 & 19.2 & 6.0 & 7.9 & 0.10 & 0.28 & 8.57 & 5.16 & 10.15 & 88 \\
\hline August 2004 & 17.4 & 5.4 & 8.3 & $<0.06$ & 0.14 & 3.50 & 5.65 & 6.89 & 61 \\
\hline November 2004 & 23.7 & 4.3 & 8.0 & 0.16 & 0.12 & 0.64 & 8.29 & 10.40 & 5 \\
\hline January 2005 & 27.0 & 4.1 & 7.9 & 0.10 & 1.00 & 4.21 & 7.20 & 14.73 & 52 \\
\hline
\end{tabular}


Table 3: Non-biomass specific uptake (v), turnover times, nitrogen fixation rates and relative preference indices (RPI) for ammonium and nitrate, in the euphotic zone in North Pine Reservoir. nd = no data. $\mathrm{NH}_{4}=$ ammonium, $\mathrm{NO}_{3}=$ nitrate, $\mathrm{PN}=$ particulate nitrogen.

\begin{tabular}{|c|c|c|c|c|c|c|c|c|}
\hline Month & $\begin{array}{c}\mathrm{v} \\
\mathrm{NH}_{4}\end{array}$ & $\begin{array}{c}\mathrm{v} \\
\mathrm{NO}_{3}\end{array}$ & $\begin{array}{l}\mathrm{NH}_{4} \\
\text { turnover (h) }\end{array}$ & $\begin{array}{c}\mathrm{NO}_{3} \\
\text { turnover (h) }\end{array}$ & $\begin{array}{c}\mathrm{PN} \\
\text { turnover (h) }\end{array}$ & $\begin{array}{l}\text { RPI } \\
\mathrm{NH}_{4}\end{array}$ & $\begin{array}{l}\text { RPI } \\
\mathrm{NO}_{3}\end{array}$ & $\begin{array}{l}\mathrm{N} \text { fixation } \\
\left(\mu \mathrm{M} \mathrm{h}^{-1}\right)\end{array}$ \\
\hline February 2004 & 0.137 & 0.165 & 5.8 & nd & 7.2 & nd & nd & $<0.005$ \\
\hline April 2004 & 0.370 & 0.019 & 0.8 & 218.0 & 2.7 & 5.3 & 0.1 & nd \\
\hline June 2004 & 0.059 & 0.041 & 0.9 & 41.8 & 24.3 & 19.9 & 0.4 & $<0.005$ \\
\hline August 2004 & 0.035 & 0.043 & 0.7 & 14.4 & 25.5 & 11.3 & 0.6 & 0.48 \\
\hline November 2004 & 0.048 & 0.007 & 0.5 & 11.0 & 17.6 & 5.5 & 0.2 & 0.24 \\
\hline January 2005 & 0.514 & 0.169 & 0.3 & 3.5 & 1.9 & 4.8 & 0.1 & $<0.005$ \\
\hline
\end{tabular}


Table 4: Primary productivity (pp) and phytoplankton biomass parameters in North Pine Reservoir. $\mathrm{I}_{\mathrm{k}}=$ light compensation point, $\alpha=$ slope of the line for photosynthesis vs. irradiance, $\mathrm{PC}=$ particulate carbon.

\begin{tabular}{|c|c|c|c|c|c|c|}
\hline Month & $\begin{array}{c}\text { Alkalinity } \\
\left(\mathrm{CaCO}_{3} \mathrm{mg} \mathrm{L}^{-1}\right)\end{array}$ & $\begin{array}{c}\text { Areal pp } \\
\left(\mathrm{g} \mathrm{C} \mathrm{m}^{-2} \mathrm{~d}^{-1}\right)\end{array}$ & 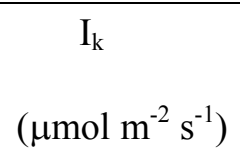 & 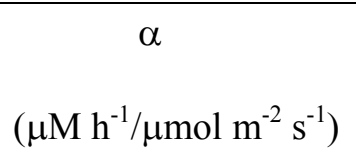 & $\begin{array}{l}\mathrm{PC} \\
(\mu \mathrm{M})\end{array}$ & $\begin{array}{l}\text { PC turnover } \\
\text { (h) }\end{array}$ \\
\hline February 2004 & 65 & 1.64 & 115 & 0.075 & 56.4 & 15 \\
\hline June 2004 & 58 & 0.50 & 190 & 0.011 & nd & nd \\
\hline January 2005 & 58 & 0.63 & 300 & 0.013 & 104.8 & 39 \\
\hline
\end{tabular}


Fig. 1

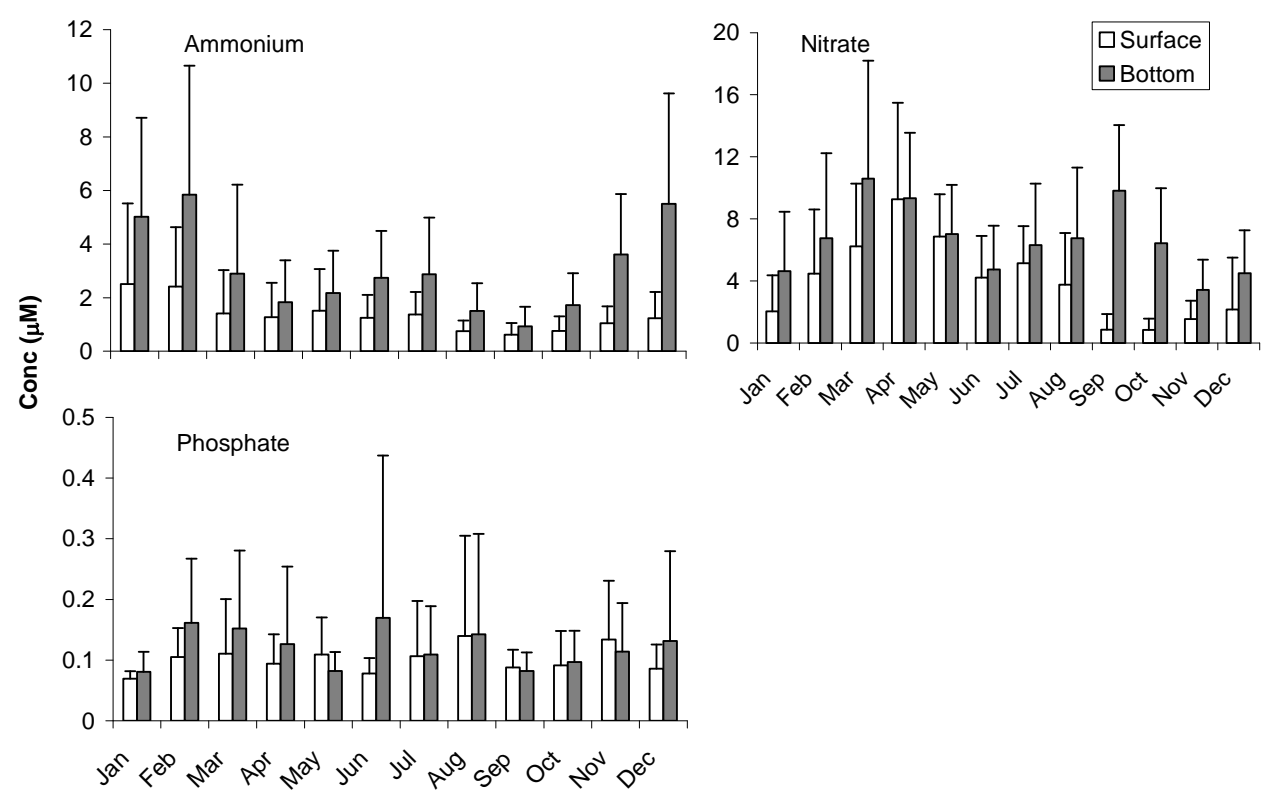




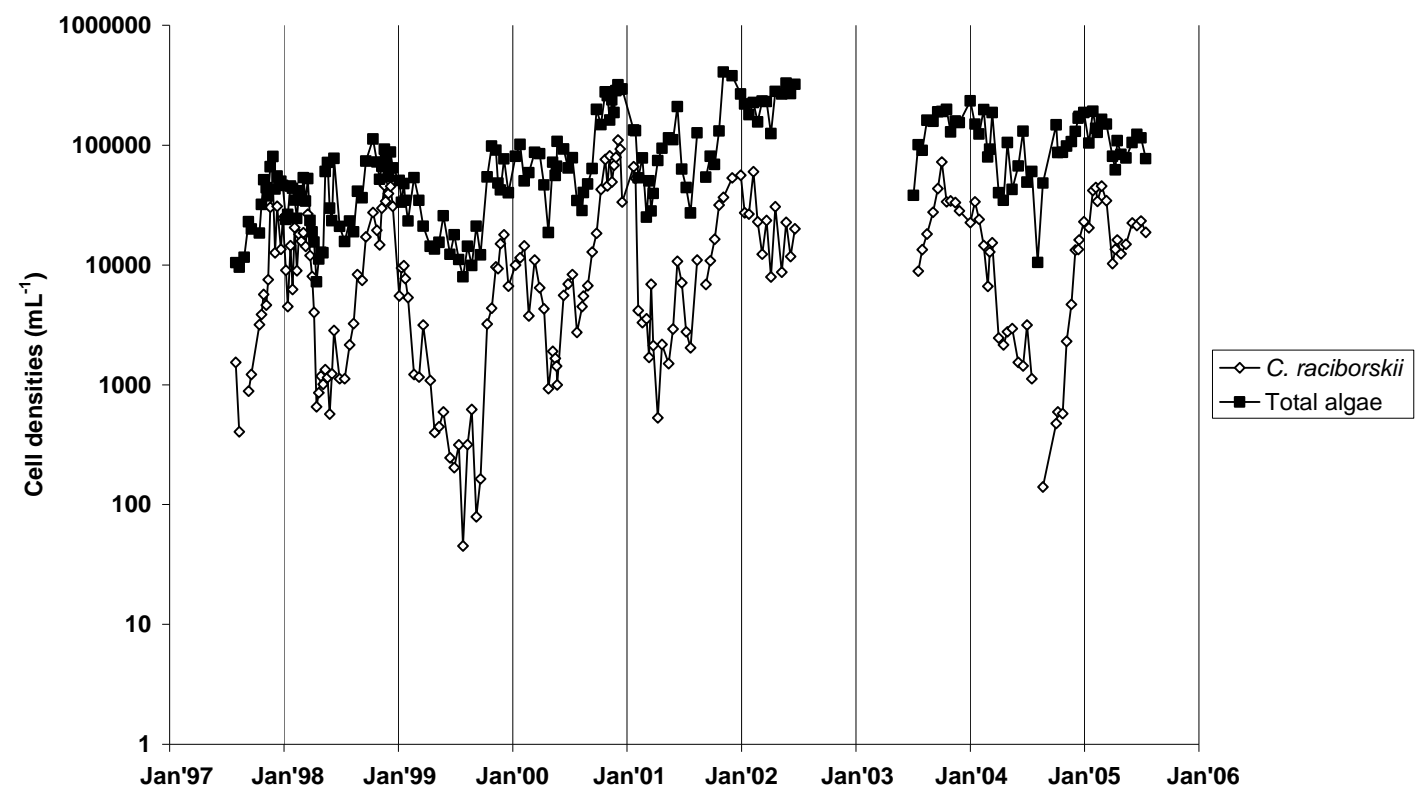

Fig. 2 


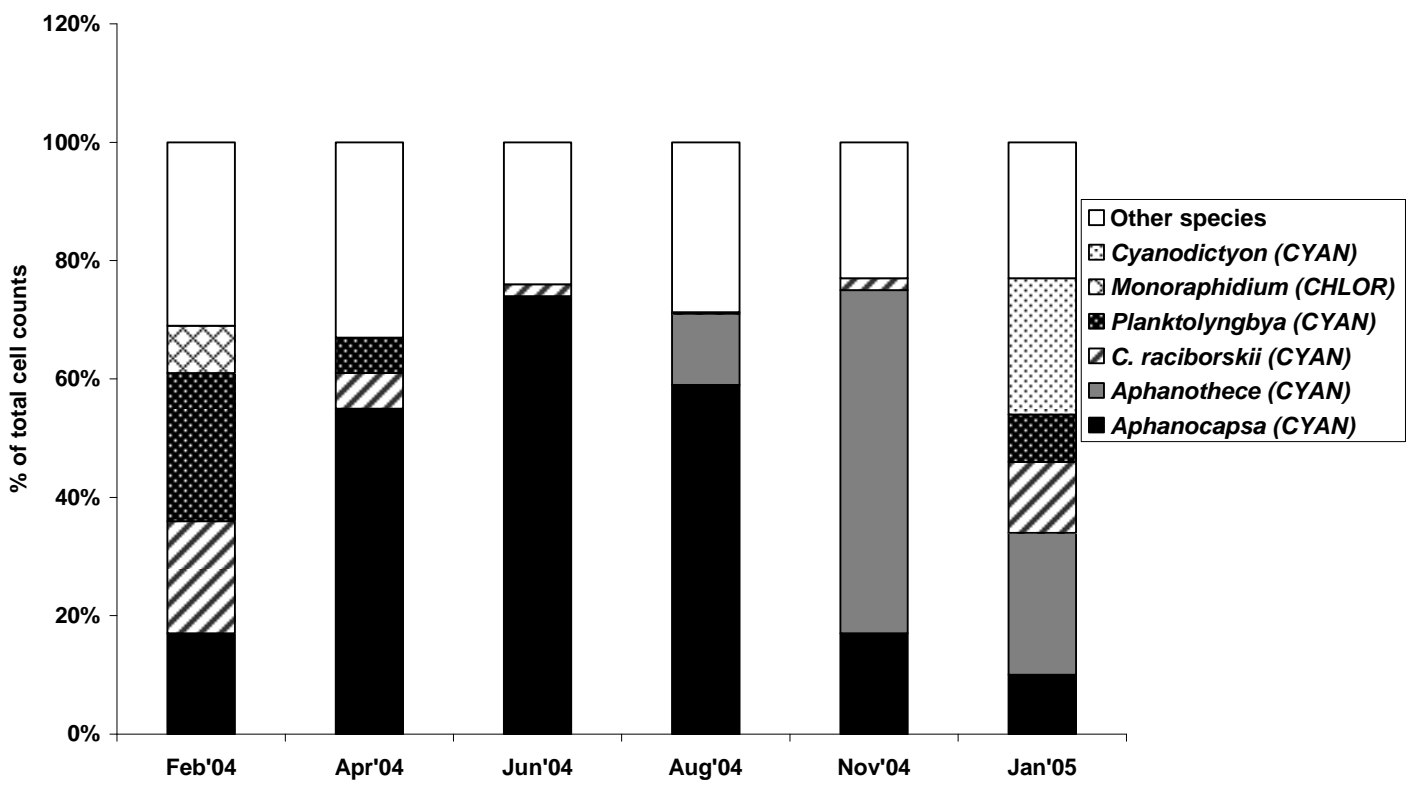

Fig. 3 
Fig. 4

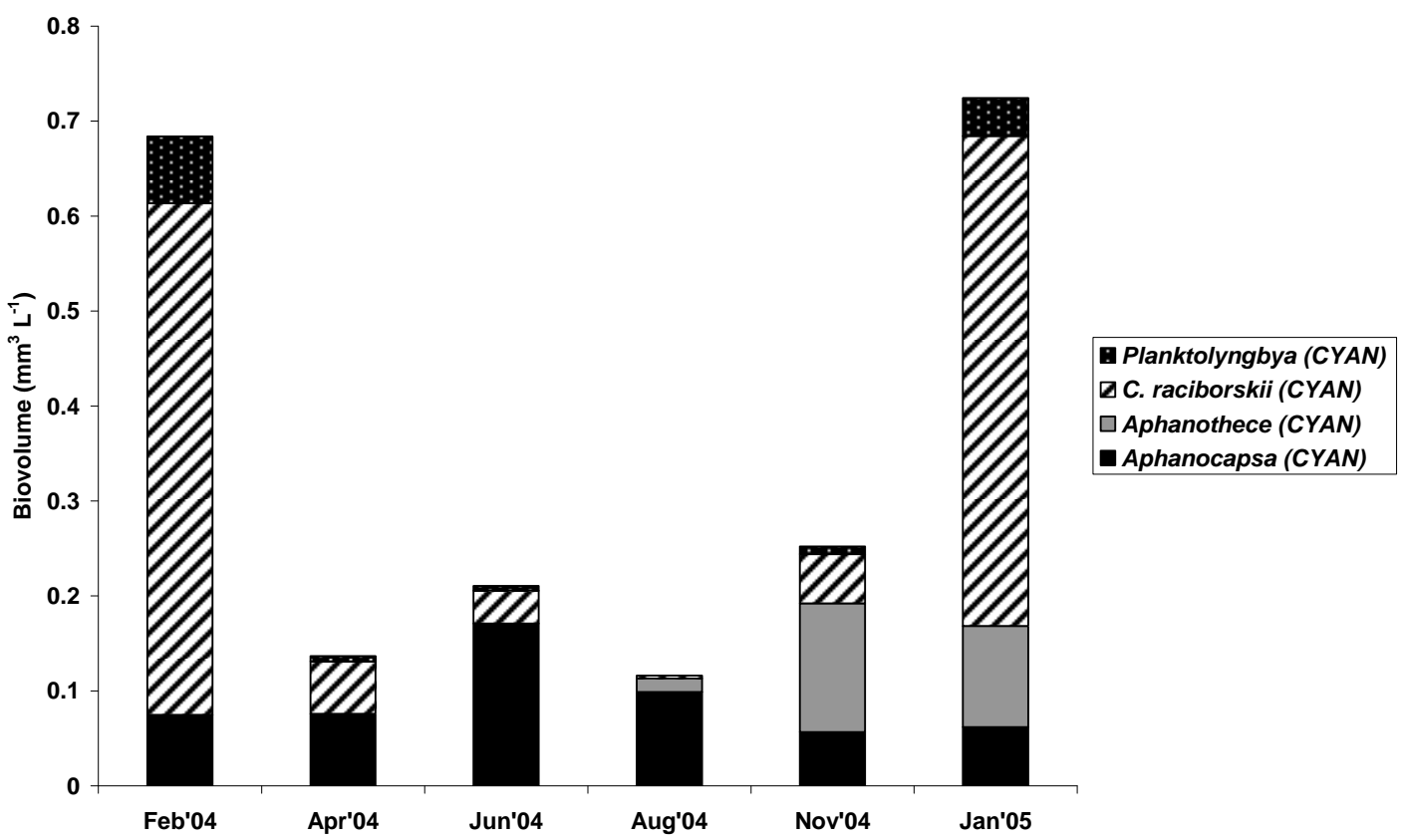


Fig.5

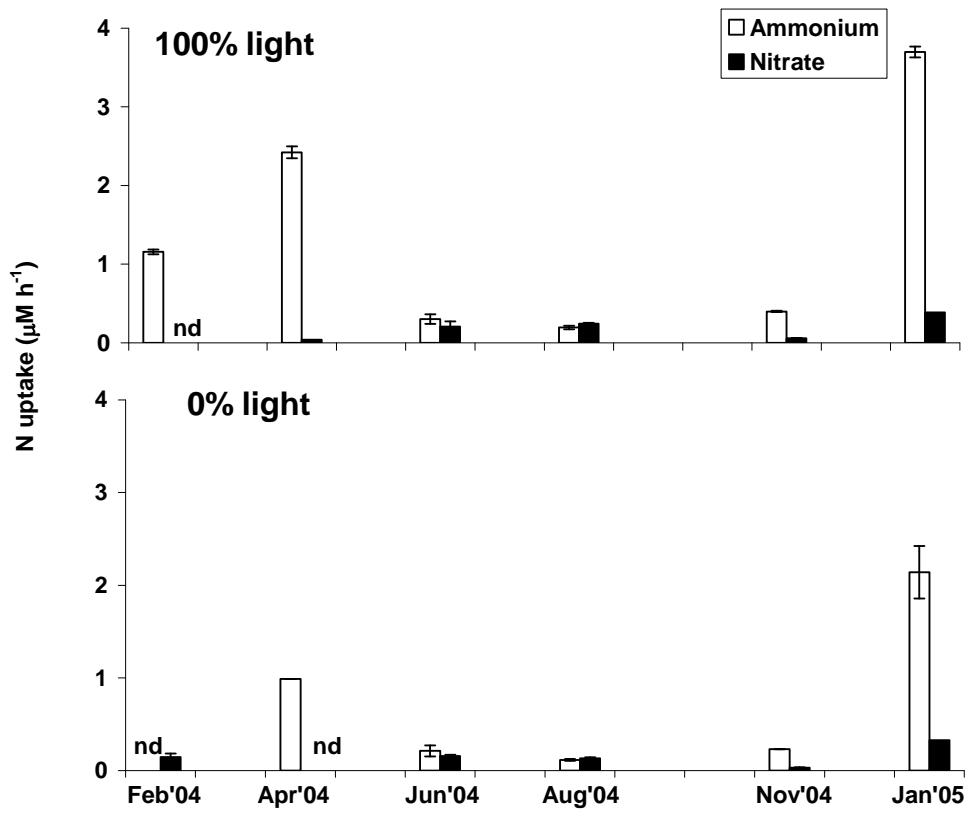


Fig. 6

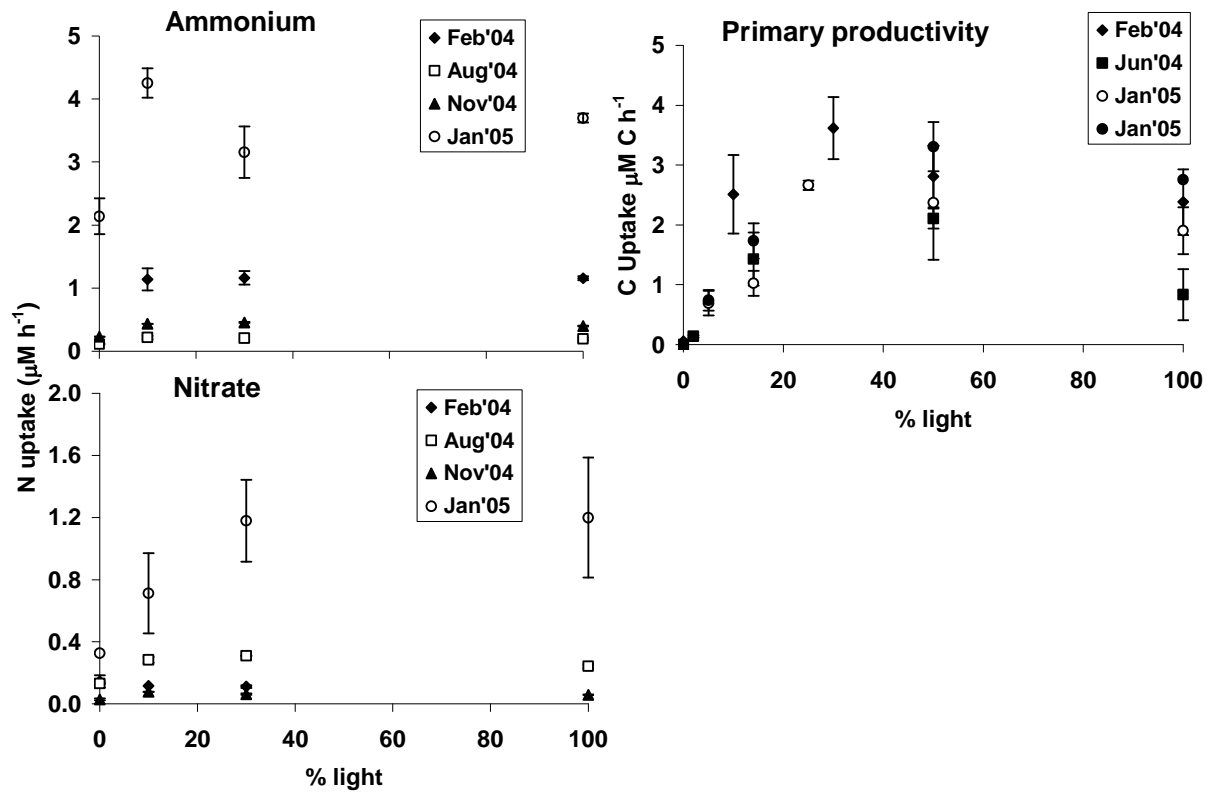


Fig. 7

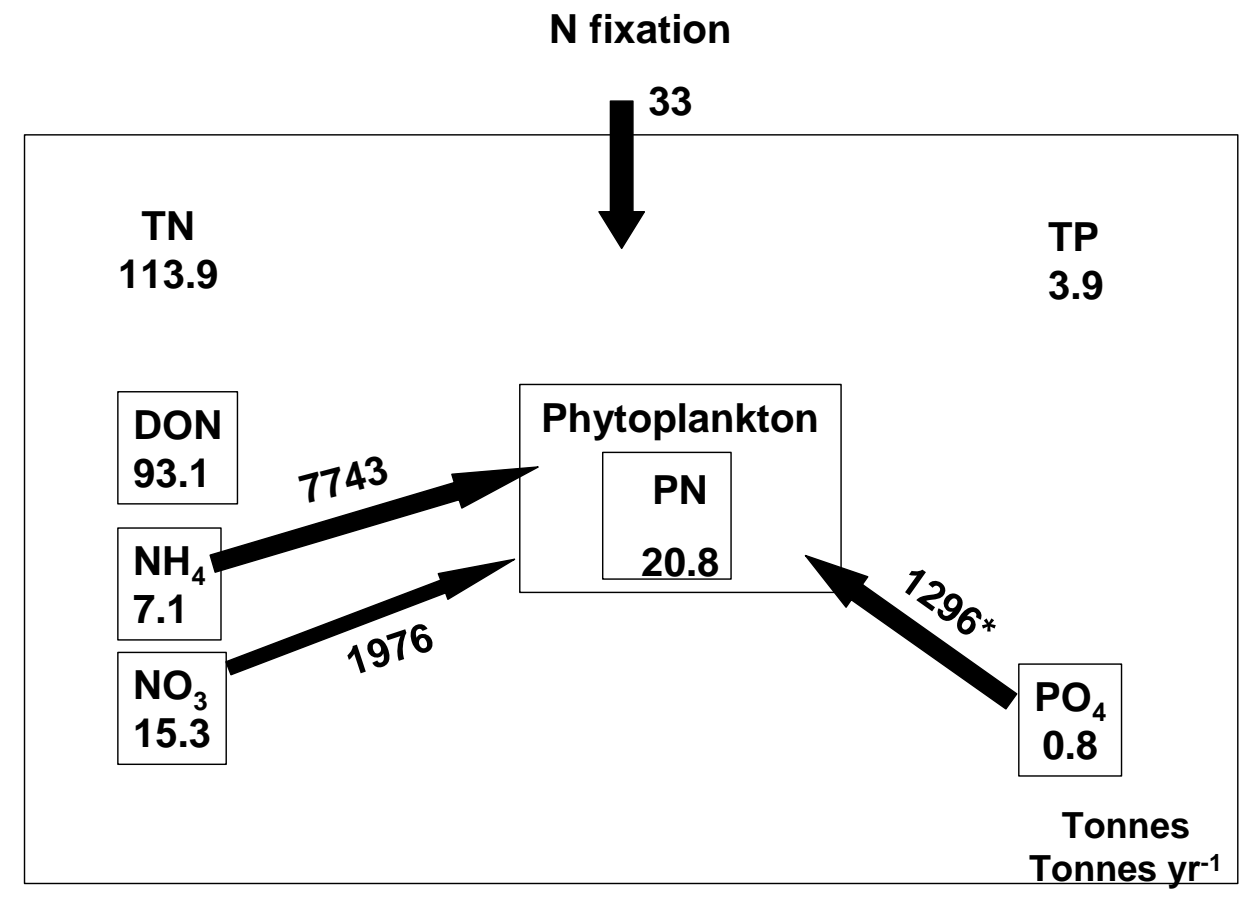

